\title{
Buyer Power in International Markets ${ }^{1}$
}

\author{
Horst Raff \\ Institut für Volkswirtschaftslehre \\ and Kiel Institute for the World Economy \\ Christian-Albrechts-Universität zu Kiel \\ 24098 Kiel, Germany \\ Email: raff@econ-theory.uni-kiel.de \\ Nicolas Schmitt ${ }^{2}$ \\ Department of Economics \\ 8888 University Drive \\ Simon Fraser University \\ Burnaby BC, V5A 1S6, Canada \\ Email: schmitt@sfu.ca
}

August 2009

\footnotetext{
${ }^{1}$ The authors acknowledge financial support from the Social Sciences and $\mathrm{Hu}-$ manities Research Council of Canada. We thank Jonathan Eaton, an anonymous referee, Peter Neary, Martin Richardson, as well conference and worshop participants for useful comments.

${ }^{2}$ Corresponding author.
} 


\begin{abstract}
This paper investigates the implications for international markets of the existence of retailers/wholesalers with market power. Two main results are shown. First, in the presence of buyer power trade liberalization may lead to retail market concentration. Due to this concentration retail prices may be higher and welfare may be lower in free trade than in autarky, thus reversing the standard effects of trade liberalization. Second, the pro-competitive effects of trade liberalization are weaker under buyer power than under seller power.

JEL classification: F12, F15, L13

Keywords: buyer power, retailing, international trade
\end{abstract}




\section{Introduction}

The present paper investigates how buyer power, that is, the exercise of significant market power by retailers/wholesalers might impact international markets and, in particular, how it may affect the volume of international trade, consumer prices and welfare. We are especially interested in determining how a reduction in trade costs affects the contractual arrangements between powerful retailers, and domestic and foreign suppliers, and what the consequences are for market outcomes.

Our analysis is motivated by the following observations. First, in many industries in which intermediaries play an important role concentration has been rising and is today often higher at the distribution level than at the manufacturing level. For instance, the five largest US grocery retailers increased their market share from 26.5\% in 1980 to $38 \%$ in 2000 (Oligopoly Watch, 2003), and Wal-Mart is today the world's biggest company by sales (US\$312.4 billion) and the number-one grocer in the US. ${ }^{1}$ Similarly, the 20 largest retailing firms in the EU account for $43 \%$ of aggregate retail food turnover whereas the equivalent number for manufacturing is $14.5 \%{ }^{2}$ This has led to significant buyer power at the retail level. Evidence concerning the exercise of such power ranges from various favorable terms obtained by major retailers (slotting allowances, listing fees, up-front fees, payments for special promotions, etc.; see Clarke et al., 2002) to refusal to purchase, product de-listing, most favored customer clauses, and exclusive arrangements. ${ }^{3}$

\footnotetext{
${ }^{1}$ Note that in the US grocery business, buyer concentration is now much higher than seller concentration despite the fact that concentration on the seller side has also risen. For instance, twenty foodmakers (e.g. Philip Morris, Nestlè) now account for $54 \%$ of checkout sales, up from about $30 \%$ in the early 1970s (Copple, 2002).

${ }^{2}$ In 2006, the four largest retailers in the UK controlled $60 \%$ of the total UK grocery sales (Competition Commission, 2007). See Dobson et al. (2001) for concentration ratios for grocery retailing in European countries, and Gereffi (1999) concerning clothing retailing.

${ }^{3}$ See Oligopoly Watch (2003), Clarke et al. (2002), and Konzelmann et al. (2007) for specific examples. Among others, cases of exclusive arrangements have emerged in the furniture industry concerning Chinese suppliers to US buyers (Sloan, 2006), and in the toy
} 
In 2000, the UK Competition Commission identified 42 buyer power practices used by five large retailers. Thirty of these practices were deemed to be anticompetitive and twenty-seven against the public interest (see Competition Commission, 2000, Table 2.14). ${ }^{4}$

Second, even large suppliers today do most of their business with a few powerful buyers. For example, there is evidence that large suppliers, such as Black and Decker, Levi Strauss, Philips, and Sara Lee, have become more and more dependent on powerful buyers, such as Wal-Mart, to the point even of being compelled to move production abroad to satisfy these buyers' requirements. Even for the newly merged Procter\&Gamble (P\&G) and Gillette, for instance, with sales in excess of $\$ 68$ billion a year, Wal-Mart is its number one customer with total orders as big as P\&G's next nine customers combined. ${ }^{5}$ Similarly, a leading German brand producer reports that $75 \%$ of its sales are going to only four retailers (Clarke et al., 2002). Using data from the US retail yogurt market, which is dominated by two main manufacturers (Dannon and General Mills), Villas-Boas (2007) finds evidence that is consistent with strong bargaining power of retailers.

Third, powerful buyers have profound effects on international markets. In its regular assessment of price dispersion for goods and services inside the EU market, the EU Commission observes that price dispersion across member states is much more significant for consumer goods than for industrial goods. It further notes that this is due in large part to 'the bargaining power and efficiency of wholesale and retail distributors' (European Commission, 2000). In other words, the lack of consumer price convergence despite free trade and

industry with the case of Toys "R" Us inducing toy makers to cut off discounters (FTC, 1998).

${ }^{4}$ Although the preliminary report did find that retailers engaged in the practice of requiring some suppliers not to sell products to any other retailers, exclusivity arrangements were not included in the final report due to insufficient evidence. See also FTC (2001) for more examples of exclusionary practices in retailing.

${ }^{5}$ 'If the relationship should go sour, it would be too bad for Wal-Mart. It would be devastating for P\&G' (Fishman, 2006, p234). 
the implementation of the single market is attributed in part to the role of intermediaries. Similarly, Javorcik, Keller and Tybout (2008) report that the main effect of the North American Free Trade Agreement on the Mexican soaps, detergents and surfactant industry is less due to the reduction in trade costs or to the entry of foreign manufacturers than to 'the fundamental change in relationship' between manufacturers and retailers once Walmex (Wal-Mart of Mexico) entered the market and exercised its bargaining power.

Not surprisingly, powerful buyers are also major participants in international markets. Wal-Mart alone accounts today for $15 \%$ of total US imports from China (Basker and Van, 2008), and imports more than half of its nonfood products (Smith, 2004). In the apparel market, $48 \%$ of the apparel sold by US retailers in 1993 were imported against $12 \%$ in $1975^{6}$, and in the socks industry, the US imported 670 million pairs of socks in 2004 against 12 million pairs in 2001 (Konzelmann et al., 2007). Greater reliance on international markets is also reflected by the fact that, by the mid-1970s, most major US retailers had overseas buying offices, especially in East Asia, with contacts with a large network of suppliers. Gereffi (1999) sees the role of 'buyer-driven global commodity chains ${ }^{77}$ as critical to understand why, despite formidable spatial and cultural distances, countries like Japan, South Korea, Taiwan, Hong Kong, Singapore, and now China have been so successful in exporting to Western countries.

The analysis of buyer power dates back to Galbraith (1952) who looked at it as a countervailing power, i.e., as offsetting manufacturers' market power. Since then the industrial organization literature has concluded that the impact of higher concentration on the buyer side of the market on consumer

\footnotetext{
${ }^{6}$ See Gereffi (1999). The picture is similar for Europe.

${ }^{7}$ In addition to large retailers, examples of buyer-driven chains include well-known marketers that carry no production such as Liz Claiborne, Nike and Reebok (see Gereffi, 1999). See also Feenstra and Hamilton (2006) who argue that the retail revolution in the US is key to understand Asia development and the different responses in Korea and Taiwan.
} 
prices and welfare was ambiguous. ${ }^{8}$ Essentially, buyer power given monopolistic power at the supplier level constitutes a second-best solution. Thus, increased buyer power can lead to lower retail prices and higher welfare provided sellers themselves have power. If however sellers have little or no power, increased buyer power unambiguously leads to higher retail prices and lower welfare.

The more recent industrial organization literature notes that buyers with market power have several different contractual tools at their disposal, and it aims at understanding the implications of some of these tools on retail prices and welfare. For instance, Marx and Shaffer (2007) show that retailers with buyer power may use up-front payments, such as slotting allowances, to exclude other retailers. Rey and al. (2005) also consider buyers' use of such contracts but, in addition, allow the terms of the contract to be conditional on exclusivity. This recent literature generally concludes that retailers with market power have considerable scope for anti-competitive behavior. The exclusion of rival retailers, in particular, increases buyer concentration, and leads to higher consumer prices and lower welfare. ${ }^{9}$

By looking explicitly at the contractual arrangements between sellers and buyers, the point of departure of the present paper is the recent literature in industrial organization. It extends the analysis to an international environment characterized by barriers to trade and asymmetries in the market shares of manufacturers. We are particularly interested in understanding how trade liberalization affects consumer prices and welfare in the presence of buyer power, and how this compares to a world in which producers have market power.

The existing international trade literature on intermediaries does not gen-

\footnotetext{
${ }^{8}$ Von Ungern-Sternberg (1996) and Dobson and Waterson (1997) show that increased concentration in the buyer market does not necessarily lead to lower consumer prices. Chen (2003) shows that an increase in countervailing power does lower retail prices provided a competitive fringe is present in retailing.

${ }^{9}$ Inderst and Wey (2006) look at suppliers' incentives to invest in product innovation in response to buyer power.
} 
erally deal with buyer power. ${ }^{10}$ Basker and Van (2008) is, to our knowledge, the only paper on buyer power in an international trade context. Their goal, however, is different from ours since they want to explain why, in the presence of economies of scale in retailing and in the import process, trade liberalization has led to an explosion of imports by a large retail chain (i.e., Wal-Mart).

We obtain two main results. First, trade liberalization in the presence of buyer power may lead to higher retail prices and lower welfare. This is due to the fact that trade liberalization may lead to an increase in market concentration in retailing. Specifically, powerful retailers may choose to use exclusive contracts that foreclose rivals in free trade but not in autarky. We find an even stronger result in the case of unilateral trade liberalization: unilateral free trade leads to lower welfare as compared to autarky unless contracts switch from being exclusive in autarky to being non-exclusive in free trade. Second, the pro-competitive effect of trade liberalization is weaker in markets with buyer power than in markets with seller power.

The paper is organized as follows. In the next section, we present a simple two-country model of international trade with two domestic retailers and one manufacturer in each country. In Section 3 we derive the equilibria in autarky and free trade. In Section 4 we compare these equilibria to determine the effect of trade liberalization on distribution contracts, retail prices and social welfare. In addition, we compare the effects of buyer power with those resulting from seller power. Conclusions follow in Section 5. All proofs can be found online ${ }^{11}$ and in Raff and Schmitt (2009).

\footnotetext{
${ }^{10}$ See Rauch (2001) on the role of networks in international trade, Feenstra and Hanson (2004) on the role of Hong Kong intermediaries with respect to Chinese products, Raff and Schmitt $(2005,2006)$ on the role of exclusive territory and exclusive dealing in international markets, and Richardson (2004) on the comparison between exclusivity in the distribution of domestic products and trade policy to restrict the market access of foreign producers. There is of course a large trade literature on vertical relationships among manufacturers (see Helpman, 2006; Spencer and Jones, 1991). The emphasis of this literature is not on buyer power either.

${ }^{11}$ At www.sfu.ca/ ${ }^{\sim}$ schmitt/buy_app.pdf.
} 


\section{The Model}

In this section, we develop a simple trade model with two identical countries, home and foreign, and segmented markets. In each country there are two differentiated retailers, who distribute a product in the local market, and one manufacturer. Whereas the retailers sell only in their local market (their services are non-tradeable), they can buy the (homogeneous) good they distribute from the local manufacturer, import it from the manufacturer located abroad, or both. Importing a good from abroad involves a trade cost of $t$ per unit. Given the additional assumption that production involves a constant marginal cost, $c$, in both countries, we can concentrate on analyzing the market equilibrium in the home country, knowing that the same analysis applies to the foreign country.

Hence consider the two home country retailers, 1 and 2, and let the marginal cost of retailing be normalized to zero. Retailer differentiation comes from the fact that they have different characteristics that consumers value, such as location, or offer different customer services. The representative domestic consumer has a quasi-linear utility function:

$$
U\left(q_{1}, q_{2}, y\right)=\sum_{i=1}^{2} q_{i}-\frac{1}{2} \sum_{i=1}^{2} q_{i}^{2}-b q_{1} q_{2}+y,
$$

where $q_{i}$ denotes the quantity of the good bought from retailer $i$, and $y$ the consumption of the numeraire good which can be traded across countries at no cost. Parameter $b \in[0,1)$ reflects the degree of substitutability between retailers. If $b=0$, retail services are not substitutable, and each retailer acts as a monopolist; if $b=1$, the retailers are perfectly substitutable. Denoting income by $I$ and the retail price of retailer $i$ by $p_{i}$, the consumer's budget constraint is

$$
\sum_{i} p_{i} q_{i}+y=I
$$

Maximizing (1) subject to (2) and inverting the resulting first-order conditions yields the following demand function for retailer $i=1,2$ : 


$$
D_{i}\left(p_{i}, p_{j}\right)=\frac{1-b-p_{i}+b p_{j}}{1-b^{2}}, \quad i \neq j .
$$

We identify buyer power with the assumption that retailers have all the bargaining power in their relationship with the manufacturers, and hence are able to make take-it-or-leave-it contract offers to the manufacturers. The contracts consist of a two-part tariff, i.e., a wholesale price and a fixed fee, and may be contingent on whether a manufacturer sells exclusively to the retailer or also supplies the other retailer. We denote the case of exclusivity by $E$ and the case of non-exclusivity by $N$. The wholesale price (fixed transfer) offered by retailer $i=1,2$ is denoted by $w_{i}^{k}\left(T_{i}^{k}\right)$, where $k=E, N$. A contract offer by retailer $i$ hence is a pair $\left(T_{i}^{E}, w_{i}^{E}\right)$ and $\left(T_{i}^{N}, w_{i}^{N}\right) \cdot{ }^{12}$ Retailers whose contracts have been accepted then choose retail prices $p_{i}, i=1,2$.

The strategic interactions between the retailers and between them and the manufacturers takes the form of the following three-stage game:

1. Retailers 1 and 2 make simultaneous contract offers to manufacturers $h$ and $f$.

2. Manufacturers $h$ and $f$ simultaneously decide whether to accept contracts from one retailer, both retailers or none of the contracts.

3. The relevant contracts are implemented and the retailers whose contracts were accepted choose retail prices simultaneously.

We solve this game for pure-strategy subgame-perfect equilibria beginning with the case of autarky, and then considering the case of non-prohibitive trade costs. In autarky retailers in the home country can only buy from manufacturer $h$, whereas with lower trade costs they may also buy from $f$.

Before presenting the details of the equilibria, it is useful to define the maximum total industry profit that could be generated by all players acting

\footnotetext{
${ }^{12} \mathrm{~A}$ retailer may offer different contracts to the two manufacturers. For notational convenience we only make this explicit - by introducing an additional subscript in the contracts - when it is necessary to avoid confusion.
} 
together as $\Pi^{m}$, and the maximum joint profit that could be earned by a single active retailer $i$ together with the manufacturers (when the other retailer does not sell) as $\Pi_{i}^{m}$. It is straightforward to show that $\Pi^{m}=\frac{(1-c)^{2}}{2(1+b)}$ and $\Pi_{i}^{m}=\frac{(1-c)^{2}}{4}$. Assuming throughout the paper that $c<1$, we have $\Pi^{m}=2 \Pi_{i}^{m}$ for $b=0$ and $\Pi^{m}<2 \Pi_{i}^{m}$ for $b>0$.

\section{Characterization of the Equilibria}

\subsection{Autarky}

There are two types of equilibria that can arise in autarky: in the first type one of the retailers has an exclusive contract with the manufacturer while the other retailer does not sell; in the second type, both retailers sell the manufacturer's product under non-exclusive contracts. Although in autarky, our model becomes an application of Lemma 1 and Proposition 2 of Rey, Thal and Vergé (2005), it is useful to characterize these equilibria in some detail.

An equilibrium in which one of the retailers has an exclusive contract with the manufacturer always exists in autarky. Simply, if retailer 1 insists on exclusivity, retailer 2 cannot do better than also insist on exclusivity, and vice versa. Retailer $i=1,2$ then offers $\widetilde{w}_{i}^{E}=c$ so as to maximize the joint profit with the manufacturer, and sets $\tilde{T}_{i}^{E}$ to transfer this profit to the manufacturer. The contract also specifies a sufficiently unattractive payment to the manufacturer in case he also sells to the rival retailer. The manufacturer accepts one of the contracts. Since the demand faced by the active retailer is simply $D(p)=1-p$, the active retailer's profit-maximizing price, given the wholesale price, is $\tilde{p}^{E}=c+\frac{1-c}{2}$. Since the two retailers are identical, the only way of making sure that the manufacturer accepts the exclusive contract is for each retailer to offer a fixed fee that shifts the entire monopoly profit to the manufacturer. Hence, in an exclusive equilibrium, both retailers earn zero profits, $\tilde{\pi}_{1}^{E}=\tilde{\pi}_{2}^{E}=0$, and the manufacturer earns 
a profit equal to $\tilde{\pi}_{h}^{E}=\Pi_{i}^{m}=\frac{(1-c)^{2}}{4}$. The intuition behind this distribution of rents is simple: the retailers are competing with each other to be the manufacturer's exclusive distributor; this competition forces them to "bid" their maximal willingness to pay for exclusivity.

There may also exist an equilibrium, in which the manufacturer accepts non-exclusive contracts so that both retailers carry the manufacturer's product. This equilibrium is characterized by two conditions. The first condition is that the wholesale price offered by a retailer has to maximize the joint profit of the retailer and the manufacturer given the wholesale price offered by the rival retailer. Hence, as proved in connection with Proposition 1 below, the equilibrium wholesale prices $\left(\tilde{w}_{1}^{N}, \tilde{w}_{2}^{N}\right)$ must satisfy

$$
\tilde{w}_{i}=\arg \max _{w_{i}}\left\{\pi_{i}\left(w_{i}, \tilde{w}_{-i}\right)+\pi_{h}\left(w_{i}, \tilde{w}_{-i}\right)\right\}, i,-i=1,2 .
$$

If this condition was not satisfied, the retailer could adjust the wholesale price, keep the profit left to the manufacturer constant by adjusting the fixed fee, and thereby raise his own profit. The second condition is that the manufacturer has to be indifferent between accepting one retailer's exclusive contract and accepting both retailers non-exclusive contracts. If the manufacturer strictly preferred the non-exclusive contract, at least one retailer could reduce his transfer to the manufacturer. Since a retailer $i$ together with the manufacturer can guarantee themselves a profit of $\Pi_{i}^{m}$ under an exclusive contract, a necessary condition for non-exclusive contracts to be accepted in equilibrium is that the profit of retailer $i$ and of the manufacturer be greater or equal to $\Pi_{i}^{m}$. Specifically, there is no deviation to exclusivity if

$$
\pi_{i}\left(\tilde{w}_{1}^{N}, \tilde{w}_{2}^{N}\right)+\pi_{h}\left(\tilde{w}_{1}^{N}, \tilde{w}_{2}^{N}\right) \geq \Pi_{i}^{m}
$$

Defining the total industry profit under a non-exclusive contract as $\tilde{\Pi}^{N}=$ $\pi_{1}\left(\tilde{w}_{1}^{N}, \tilde{w}_{2}^{N}\right)+\pi_{2}\left(\tilde{w}_{1}^{N}, \tilde{w}_{2}^{N}\right)+\pi_{h}\left(\tilde{w}_{1}^{N}, \tilde{w}_{2}^{N}\right)$, we can rewrite $(5)$ as $\tilde{\Pi}^{N}-\Pi_{1}^{m} \geq$ $\pi_{2}\left(\tilde{w}_{1}^{N}, \tilde{w}_{2}^{N}\right)$ when $i=1$. Since $\pi_{2}\left(\tilde{w}_{1}^{N}, \tilde{w}_{2}^{N}\right) \geq 0$, the condition under which 
both retailers are active is ${ }^{13}$

$$
\tilde{\Pi}^{N} \geq \Pi_{i}^{m}
$$

Proposition 1 summarizes the discussion: ${ }^{14}$

Proposition 1 In autarky, an equilibrium with exclusive contract always exists. If $b \leq 0.73205$, there also exists an equilibrium under which both retailers buy from the manufacturer under non-exclusive contracts.

It is easy to determine that retail prices in the non-exclusive equilibrium are:

$$
\tilde{p}_{i}^{N}=c+\frac{(2-b)(1-c)}{4}
$$

Not surprisingly, $\tilde{p}_{i}^{N}<\tilde{p}^{E}$ for $b>0$ so that the non-exclusive-contract equilibrium induces more competition than the exclusive-contract one. Obviously, the retailers need to be sufficiently differentiated for the non-exclusive equilibrium to exist. Only in this case are rents large enough to prevent retailers from deviating by offering an exclusive distribution arrangement to the manufacturer. More precisely, the rents obtained by each retailer correspond to his contribution to total industry profit (i.e., the difference between industry profit in the non-exclusive equilibrium and the joint profit that the manufacturer and the other retailer could generate by agreeing on an exclusive deal). The remaining rent goes to the manufacturer.

\subsection{Non-prohibitive Trade Cost}

Now consider equilibrium contracts when the trade cost is sufficiently low to enable retailers to buy from abroad. Suppose there exists an equilibrium in

\footnotetext{
${ }^{13}$ See Rey et al.(2005) for the original proof. A generalization of this result is provided in Lemma 1 below.

${ }^{14}$ Rey et al. (2005) argue that, from the retailers' point of view, an exclusive equilibrium is payoff dominated by an equilibrium with non-exclusive contracts, and invoke cheap-talk between the retailers to eliminate the payoff-dominated equilibria. We choose instead to work with all possible equilibria.
} 
which both retailers sell a positive quantity. The profits of retailer $i=1,2$ and the manufacturers will then typically be functions of the trade cost $t$. Like in autarky, a necessary condition for the existence of such an equilibrium is that the total industry profit, in this case denoted by $\Pi^{N}(t)$, be higher than the joint profit that can be earned when one retailer sets up an exclusive arrangement that monopolizes the retail market. That is, the possibility of foreclosure limits how much rent retailers may earn in an equilibrium with non-exclusive contracts, and guarantees that at least one manufacturer earns a positive profit. The maximum rent that can be earned in an exclusive arrangement is achieved when the retailer satisfies his entire demand by buying from the local manufacturer. This rent is hence independent of the trade cost and given by $\Pi_{i}^{m}=\frac{(1-c)^{2}}{4}$, just like in autarky. In particular, we can prove the following result:

Lemma 1 Suppose an equilibrium exists in which both retailers are active. Then it is necessarily the case that $\Pi^{N}(t) \geq \Pi_{i}^{m}$, and that the sum of manufacturers' profits is positive.

In autarky both retailers have to buy from the local manufacturer. Will they still do so if trade is liberalized? To see that it cannot be the case for a sufficiently low trade cost, suppose that an equilibrium with two active retailers exists, and that the trade cost is zero. We know from Lemma 1 that, in such an equilibrium, the two manufacturers together have to earn positive profits. Consider two cases: first, both retailers buy all their goods from the same manufacturer. This implies that this manufacturer earns positive profit, whereas the inactive manufacturer earns zero profit. This cannot happen in equilibrium: a retailer would benefit from deviating and buying from the inactive manufacturer since he would have to offer him only an infinitesimally small transfer. Second, one retailer buys positive quantities from both manufacturers. This cannot occur in equilibrium, since the retailer can procure all of his goods from one manufacturer in exchange 
for an infinitesimally higher transfer to that manufacturer, thereby saving the rent transferred to the other manufacturer. The same arguments have to hold if the trade cost is positive but sufficiently small. This proves the following Lemma:

Lemma 2 If an equilibrium exists in which both retailers are active and if the trade cost is sufficiently low, each retailer buys from a different manufacturer.

Note that each retailer does not need to forbid its supplier to sell to the rival retailer in this two-retailer-two-manufacturer environment. It is simply in the interest of each retailer not to buy from several manufacturers. Strictly speaking, the contracts are therefore non-exclusive, even though they have the appearance of exclusive contracts because each manufacturer supplies a different retailer.

The fact that each retailer buys from a separate manufacturer when the trade cost is sufficiently small has implications for wholesale prices and ultimately for the degree of competition between retailers. If retailer 1 is the one who buys from the domestic manufacturer, his wholesale price has to maximize their joint profit given retailer 2's wholesale price. That is, the objective function is $\left(p_{1}\left(w_{1}, w_{2}\right)-c\right) q_{1}\left(w_{1}, w_{2}\right)$. The wholesale price of retailer 2 who imports goods from the foreign manufacturer maximizes $\left(p_{2}\left(w_{1}, w_{2}\right)-c-t\right) q_{2}\left(w_{1}, w_{2}\right)$. Let $\hat{w}_{1}^{N}$ and $\hat{w}_{2}^{N}$ denote the corresponding Nash equilibrium wholesale prices.

These objective functions differ from those in autarky, where both retailers purchase from the domestic manufacturer in one important respect. In autarky, a retailer has to take into account that, by lowering the wholesale price and therefore also his retail price, the manufacturer loses sales to the rival retailer. The manufacturer only accepts a reduction in the wholesale price if he receives compensation for these lost sales. When the trade cost is sufficiently low so that each retailer buys from a separate manufacturer, the incentive to reduce wholesale prices is larger than in autarky simply because 
there is no need to compensate the manufacturer for any lost sales to the rival. In other words, if the trade cost is sufficiently small, retailers engage in tougher price competition than in autarky.

The tougher competition between retailers induced by low trade costs has implications for the equilibrium contracts. In particular, if both retailers are active, the total industry profit for sufficiently low $t$ is smaller than the total industry profit in autarky: $\Pi^{N}(t)<\tilde{\Pi}^{N}$. Since the maximum profit that can be earned in an exclusive distribution arrangement in which one retailer is foreclosed, $\Pi_{i}^{m}$, is independent of $t$, this means that there may be situations in which an equilibrium with two active retailers exists in autarky but does not exist for a sufficiently low trade cost. In other words, we may observe that $\Pi^{N}(t)<\Pi_{i}^{m}<\tilde{\Pi}^{N}$ so that the necessary condition for the existence of an equilibrium in which both retailers are active holds in autarky but not in free trade.

Figure 1 generalizes the above idea since we know that $\Pi^{N}(t)$ and $\tilde{\Pi}^{N}$ are decreasing functions of $b$, whereas $\Pi_{i}^{m}$ is independent of $b$. This means that, given a sufficiently low $t$, there is a range of $b$ 's $(\widehat{b}(t) \leq b \leq \widetilde{b}$ in Figure 1) for which there may exist an equilibrium in which both retailers are active in autarky but not for $t$ close enough to zero. In other words, by increasing competition under non-exclusive contracts, trade liberalization may induce exclusive contracts and monopolization of the retail market.

To formally establish this possibility, we provide a full characterization of the equilibria in free trade, and then compare the equilibria under autarky and free trade. The following proposition summarizes the equilibrium outcomes in free trade:

Proposition 2 If $b \leq 0.67209$, there exists an equilibrium in free trade in which both retailers are active, each buying from a separate manufacturer. If $b \geq 0.61803$, there exists an equilibrium in free trade in which only one retailer is active; this retailer has exclusive contracts with both manufacturers. 
It should be clear that, with two manufacturers, it is more difficult for a retailer to foreclose his rival than in autarky since he would have to sign exclusivity contracts with both manufacturers. Indeed, suppose that retailer 1 offers an exclusive contract to both manufacturers. He has to offer both of them the same payment since, otherwise, retailer 2 would find it easier to convince the manufacturer receiving the less advantageous deal from retailer 1 to sell to him. The best deal that 1 can offer is to set the wholesale price equal to the manufacturers' marginal cost and to pay each manufacturer a fixed fee equal to half the monopoly profit that he earns. But we also must check retailer 2's best response. Obviously, he cannot offer more than retailer 1 if he were to make offers to both manufacturers. But retailer 2 could also make an offer to just one manufacturer. Naturally, one does not expect that such an offer will be profitable for a manufacturer if price competition between retailers is tough enough, i.e., if $b$ is sufficiently close to one.

In the free-trade equilibrium in which both retailers are active, the retail price charged by retailer $i$ can be shown to be

$$
\hat{p}_{i}^{N}=c+\frac{2(1-b)(1-c)}{4-b(2+b)} .
$$

Each retailer earns a profit equal to his contribution to overall industry profit, and, as pointed out in Lemma 1, the manufacturers make positive profits.

In the exclusive-contract equilibrium, we obviously obtain the same retail price as in the equivalent autarky equilibrium, namely $\widehat{p}^{E}=c+\frac{1-c}{2}$. Both domestic retailers earn zero profits, $\widehat{\pi}_{1}^{E}=\widehat{\pi}_{2}^{E}=0$, whereas the two manufacturers share the resulting industry profits equally. Since the two countries are identical, the active foreign retailer also divides his entire profits equally between the two manufacturers. Thus, the domestic manufacturer makes the same overall profit in the exclusive equilibrium as in the equivalent autarky equilibrium, namely $\widehat{\pi}_{h}^{E}=\frac{(1-c)^{2}}{4}$; however, in this case, the profit is the sum of payments from the active retailers in both countries. 
Obviously, trade liberalization has effects on consumer prices, consumer surplus and profits. These effects come from two sources. First, if both retailers are active before and after trade liberalization, they pay different wholesale prices and charge different consumer prices in equilibrium. Second, free trade may involve a switch in contract either from exclusivity to nonexclusivity or the other way round. Retail market structure would then change from a retail monopoly to a retail duopoly or vice versa.

\section{The Effects of Trade Liberalization}

\subsection{Prices and Welfare}

We can now compare equilibrium distribution arrangements and their effects on retail prices and welfare in free trade and autarky. The outcome depends on the type of contract observed in the autarky equilibrium and on the degree of differentiation between the two retailers (i.e., the value of $b$ ). The results are summarized below:

Proposition 3 A. Suppose the autarky equilibrium involves exclusive contracts. Then in free trade: (i) if $b \leq 0.61803$, both retailers switch to non-exclusive contracts and retail prices are lower than in autarky; (ii) if $0.61803<b \leq 0.67209$, either there is still an equilibrium with exclusive contracts, or both retailers switch to non-exclusive contracts. In the former case, retail prices remain constant; otherwise they are lower than in autarky; (iii) if $b>0.67209$, contracts remain exclusive and retail prices do not change.

B. Suppose the autarky equilibrium involves non-exclusive contracts. Then in free trade: (i) if $b \leq 0.61803$, there is no change in contracts but retail prices are lower than in autarky; (ii) if $0.61803<b \leq 0.67209$, either there is still an equilibrium with non-exclusive contracts and prices are lower than in autarky, or contracts switch to being exclusive and 
prices are higher than in autarky; (iii) if $0.67209<b \leq 0.73205$, retailers adopt exclusive contracts and prices are higher than in autarky.

Not surprisingly, free trade tends to lead to more competition and lower retail prices given exclusive contracts in autarky. This is especially true when retailers are poor substitutes, since in this case retail market structure changes from a monopoly to a duopoly as retailers switch to non-exclusive contracts. Free trade also leads to more competition and lower prices for consumers when contracts are non-exclusive in both autarky and free trade. The reason is that in autarky each retailer internalizes the effect of his wholesale price on the single manufacturer. Specifically, reducing the wholesale price means that the retailer has to compensate the manufacturer for lost sales to the rival retailer. This keeps wholesale prices and, therefore, retail prices high. In free trade, each retailer buys from a different manufacturer. There is thus no need to compensate the supplier for any lost sales to the rival retailer. This makes it more attractive to lower the wholesale price in order to take market share away from the rival retailer, reducing retail prices in the process.

Trade liberalization may also lead to a retail monopoly. This is the case when autarky involves non-exclusive contracts and retailers are close substitutes. The intuition for this surprising result is simple: because trade liberalization would lead to much tougher price competition if there were no monopoly, each retailer has an incentive to try even harder to foreclose his rival by imposing an exclusive contract on the manufacturers.

Interestingly, trade liberalization in markets with buyer power, instead of creating more competition as one might expect, may thus have the exact opposite effect. Indeed, Case B.(iii) is one where the concentration ratio in retailing is unambiguously higher in free trade than in autarky. Although, in both cases, there is just one manufacturer selling, the distribution sector features two active retailers in autarky but only one in free trade. 
Next, we examine how bilateral trade liberalization affects domestic social welfare. Domestic social welfare $(W)$ consists of the sum of consumer surplus $(C S)$, the two domestic retailers' profits $\left(\pi_{i}\right)$ and the domestic manufacturer's profit $\left(\pi_{h}\right)$ :

$$
W=C S+\sum_{i=1}^{2} \pi_{i}+\pi_{h} .
$$

The following welfare results mirror the effect of trade liberalization on consumer prices:

Proposition 4 In the presence of buyer power, bilateral trade liberalization implies that domestic social welfare: (i) increases if $b \leq 0.61803$; (ii) increases, remains unchanged or decreases if $0.61803<b \leq 0.67209$; and (iii) decreases or remains unchanged if $b>0.67209$.

Trade liberalization raises social welfare (Cases i-ii) because it leads to tougher price competition and hence a smaller deadweight loss. This is reminiscent of traditional trade models except that the pro-competitive effect now occurs in retailing rather than in manufacturing. The fact that welfare may fall (Cases ii-iii) is due to the fact that contracts may switch from nonexclusive in autarky to exclusive in free trade. In this case, the retail price increases as one retailer monopolizes the market in free trade. The result that domestic welfare may remain unchanged (Cases ii-iii) arises when only one retailer is active in both countries in free trade and in autarky. In this case, retail prices and hence consumer surplus are unchanged, and the active domestic retailer's transfer of rents to the foreign manufacturer is just offset by the active foreign retailer's transfer of rent to the home manufacturer.

If the home government liberalizes trade unilaterally, these offsetting transfers by the foreign retailer to the domestic manufacturer no longer take place. In this case, the foreign manufacturer receives a significant share of the home industry profit in free trade. This is straightforward in the case of exclusive contracts: half the domestic industry profit now goes to the 
foreign manufacturer to prevent him from accepting an exclusive contract from the rival retailer. When contracts are non-exclusive, the reason that the foreign manufacturer, like his domestic counterpart, receives a positive profit is that here, too, he has to be compensated for not signing an exclusive contract with the rival retailer. Hence the rather paradoxical result that, despite buyer power, free trade induces a significant shift of rents to the foreign manufacturer. It is only in the case where contracts switch from exclusivity in autarky to non-exclusive contracts in free trade that this transfer of rents abroad does not more than offsets the positive effect of trade liberalization on consumer surplus. In all the other cases, the shift of rents to the foreign manufacturer comes on top of the fact that trade liberalization may lower consumer surplus or leave it unchanged. Hence we obtain the following clear-cut result:

Proposition 5 In the presence of buyer power, unilateral trade liberalization unambiguously reduces domestic social welfare unless contracts are exclusive in autarky and non-exclusive in free trade.

\subsection{Buyer versus Seller Power}

The size of the rents accruing to the retailers and to the manufacturers is obviously not the same whether it is the retailers or the manufacturers who have all the bargaining power. But this is not the main difference between seller and buyer power. In this section, we want to point out another key difference, namely that the equilibrium prices and consequently the competitive effects of free trade are different.

To see this, assume that the manufacturers have all the bargaining power and make take-it-or-leave-it contract offers to the two retailers. In autarky and thus in the presence of a single manufacturer and two retailers, manufacturer $i$ sets a wholesale price equal to

$$
\bar{w}_{i}=c+\frac{b(1-c)}{2} .
$$


Equilibrium retail prices are

$$
\bar{p}_{i}=c+\frac{1-c}{2},
$$

and the manufacturer uses the fixed fee to extract all profits from the retailers. Hence, the manufacturer's profit is equal to the overall integrated profit $\Pi^{m}$ :

$$
\bar{\pi}^{m}=\Pi^{m} \equiv \frac{(1-c)^{2}}{2(1+b)} .
$$

The manufacturer is thus able to completely monopolize the market. He does so by setting a high wholesale price that internalizes the competition between the retailers. Obviously then, the profit earned by the manufacturer is higher than in the exclusive-contract equilibrium with buyer power, since in the latter equilibrium only one retailer is active. It is also higher than in the non-exclusive-contract equilibrium. More significantly, it leads to retail prices in autarky that are at least as high under seller power as under buyer power. To show this, it suffices to compute $\left(\bar{p}_{i}-\widetilde{p}_{i}^{N}\right)$ as given by (10) and (7) respectively, which yields

$$
\bar{p}_{i}-\widetilde{p}_{i}^{N}=\frac{b(1-c)}{4}>0 .
$$

The retail prices are of course identical under seller power and under buyer power when there are exclusive contracts in the latter case.

Next, we examine contracts and retail prices under free trade. The first step is to prove that with seller power we do not obtain equilibria in which one of the manufacturers is excluded from the market:

Lemma 3 Under seller power there does not exist an equilibrium in which in free trade both retailers buy from only one manufacturer under an exclusive contract, and the other manufacturer does not sell.

The reason for this result is as follows: a manufacturer wishing to impose an exclusive contract can offer each retailer at most a profit of $\bar{\pi}^{m} / 2$ to 
prevent them from buying from the rival manufacturer. As indicated above, the retail price would have to be equal to $\bar{w}_{i}$ to realize these profits. However, by setting a lower wholesale price, the inactive manufacturer can generate a rent that is greater than $\bar{\pi}^{m} / 2$ so that it can induce one of the retailers to break the exclusive contract.

This leaves the case of non-exclusive contracts. The setting where manufacturers make non-exclusive contract offers to retailers has been examined by Shaffer (1991). In Shaffer's paper there is a continuum of manufacturers. However, it is straightforward to show that his result also holds for the case of two homogenous manufacturers, one in each country. Moreover, the equilibrium retail prices that Shaffer obtains are the same as those we computed for the non-exclusive-contract equilibrium under buyer power. ${ }^{15}$ If free trade leads to an exclusive-contract equilibrium under buyer power, then retail prices must obviously be higher than under seller power.

Proposition 6 summarizes the above discussion.

Proposition 6 The autarky retail prices are never lower under seller power than under buyer power. The free-trade retail prices are the same under buyer and seller power if $b \leq 0.61803$; but buyer power leads to identical or to higher retail prices in free trade than seller power if $b>0.61803$.

An immediate corollary emerges from Proposition 6:

Corollary 1 The pro-competitive effect of free trade (as compared to autarky) is unambiguously greater under seller power than under buyer power.

This is the case because, as compared to seller power, buyer power tends to lead to more price competition in autarky (the two retailers are active

\footnotetext{
${ }^{15}$ This is due to the fact that in the non-exclusive-contract equilibrium - just like in Shaffer (1991) - each retailer buys from a single manufacturer, so that equilibrium wholesale price maximizes the joint profit of a retailer/manufacturer pair given the equilibrium price of the other pair. However, the rents are shared differently between retailers and manufacturers, with manufacturers obtaining a positive share under buyer power and zero profit under seller power.
} 
despite a single source of supply) but not in free trade where price competition is either as intense as under seller power (when both retailers are active) or less intense when one of the retailers is foreclosed.

\section{Conclusions}

Opening up markets to the forces of international trade has traditionally been seen as a policy tool capable of unleashing pro-competitive forces and inducing domestic industries that are imperfectly competitive to become more competitive and more efficient. In essence, opening a country to international trade allows for rents to be dissipated to the benefit of consumers. Typically in such a situation, the pro-competitive effects of freer trade are thought to be large not only because barriers that distort trade are being eliminated, but also because market power gets diluted. This process has surely been present in many liberalization episodes. However, producers' rents may not always be dissipated by competition. There are often other agents ready to capture a share of these rents if they have an opportunity to do so. This is the case for intermediaries, especially if they are unavoidable agents in the process of reaching consumers. Since the economic power of these intermediaries is on the rise and since one can naturally expect them to play a significant role in distributing foreign products, it is important to understand better their role in international markets.

This paper has started to look at the implications of the existence of such agents when they have buyer power, i.e., when they have sufficient market power to make take-it-or-leave-it offers to producers. The main conclusions are that trade liberalization could bring less competition and lower welfare, and that pro-competitive effects tend to be smaller under buyer power than under seller power. Thus, big retailers like Wal-Mart may have non-trivial trade liberalization effects. The results of the present paper are also consistent with the EU Commission's intuition that different degrees of buyer 
power across the EU might help explain the lack of significant price convergence for consumer goods within the EU. In short, the role of buyer power may help explain why competitive and welfare gains from the 1992 EU single market experiment have been lower than expected (see Grin, 2003, for a full discussion). We also obtain some surprising results along the way. In particular, the rents existing at the manufacturer level in autarky may continue to be completely captured by manufacturers in free trade even if there is an additional source of supply and (imperfect) competition among retailers. In other words, buyer power by itself does not necessarily imply that retailers capture the rents generated by trade liberalization at the expense of manufacturers.

It is easy to modify that last outcome by introducing heterogeneity among retailers and, in particular, by assuming that retailer 1 faces a lower unit retail cost than retailer 2 . This has two main implications. The first and obvious one is that, in an equilibrium with exclusive contracts, retailer 1 is not only the sole active retailer but also earns positive profits. Hence retailer 1 now shares rents with the manufacturers. Not surprisingly, the greater the difference between the retailing unit costs, the greater the profit earned by the active retailer. ${ }^{16}$ The second implication is that asymmetric retail costs change the retailers' incentives to adopt exclusive contracts. In particular, the low-cost retailer now has an advantage over the high-cost retailer that in itself gives him an incentive to exclude the high-cost retailer. It is then not surprising to find that, with retail cost asymmetry, the range of values of b over which exclusive contracts arise in equilibrium unambiguously increases as compared to the case with symmetric retail costs. In other words, with asymmetric retail costs, retailers can be less differentiated before an exclusive equilibrium emerges than they need to be without them. Of course, increasing the number of manufacturers would make foreclosure more

\footnotetext{
${ }^{16}$ Specifically, retailer 1's net profit is $\pi_{1}=\frac{1}{4}\left(1-c_{1}-c\right)^{2}-\frac{1}{4}\left(1-c_{2}-c\right)^{2}$ and the manufacturer profit is $\frac{1}{4}\left(1-c_{2}-c\right)^{2}$ where $c_{1}\left(c_{2}\right)$ is retailer 1 (retailer 2)'s unit cost.
} 
difficult. But the above discussion suggests that exclusive contracts would still be possible at least in the presence of sufficient asymmetries among retailers.

It is important to keep in mind that the present paper does not propose a theory of buyer power since buyer power in our model is exogenous: the retailers have all the bargaining power irrespective of the trade environment. It only spells out the implications of the existence of buyer power in an international context. This is of course a first step, one that already produces interesting results that differ substantially from those associated with seller power. Thus the present paper has nothing to say with respect to the idea that buyer power might be a by-product of freer trade. It should be clear, however, that if it is true that trade liberalization is an important element in the emergence of buyer power, then our main conclusions would hold $a$ fortiori.

\section{References}

[1] Basker, E., Van, P.H., 2008. Wal-Mart as catalyst to US-China trade, University of Missouri, mimeo.

[2] Clarke, R., Davies, S., Dobson, P., Waterson, M., 2002. Buyer Power and Competition in European Food Retailing. Edward Elgar, Cheltenham.

[3] Chen, Z., 2003. Dominant retailers and the countervailing-power hypothesis. RAND journal of Economics 34, 612-625.

[4] Competition Commission, 2000. Supermarkets: A report on the supply of groceries from multiple stores in the United Kingdom, www.competitioncommission.org.uk/rep_pub/reports/2000/446super.htm.

[5] Competition Commission, 2007. The Supply of Groceries in the UK Market Investigation, www.competition- 
commission.org.uk/inquiries/ref2006/grocery/provisional_findings.htm, Provisional findings report.

[6] Copple, B., 2002. Shelf-Determination, April 15, forbes.com/forbes/2002/0415/130_print.html

[7] Dobson, P., Clarke, R., Davies, S., Waterson, M., 2001. Buyer power and its impact on competition in the food retail distribution sector of the European Union. Journal of Industry, Competition and Trade 1, $247-281$.

[8] Dobson, P., Waterson, M., 1997. Countervailing power and consumer prices. Economic Journal 107, 418-430.

[9] European Commission, 2000. Single Market Scoreboard. November, No 6 , Brussels.

[10] Feenstra, R., Hanson, G., 2004. Intermediaries in entrepôt trade: Hong Kong re-exports of Chinese goods. Journal of Economics and Management Strategy 13, 3-35.

[11] Feenstra, R., Hamilton, G., 2006. Emergent Economies, Divergent Paths: Economic Organization and International Trade in South Korea and Taiwan. Cambridge University Press, Cambridge.

[12] Fishman, C., 2006. The Wal-Mart Effect. Penguin Press, New York.

[13] Federal Trade Commission, 1998. In the Matter of Toys "R" Us Inc, Final Order, Docket 9278, October 13.

[14] Federal Trade Commission, 2001. Report on the FTC Workshop on Slotting Allowances and Other Marketing Practices in the Grocery Industry, February.

[15] Galbraith, J.K., 1952. American Capitalism: The Concept of Countervailing Power. Houghton Mifflin, New York. 
[16] Gereffi, G., 1999. International trade and industrial upgrading in the apparel commodity chain. Journal of International Economics 48, 3770 .

[17] Grin, G., 2003. The Battle of the Single European Market. European Studies Series. Kegan Paul, London.

[18] Helpman, E., 2006. Trade, FDI, and the organization of the firm. Journal of Economic Literature 44, 589-630.

[19] Inderst, R., Wey, C., 2006. Buyer power and supplier incentives. European Economic Review 51, 647-667.

[20] Javorcik, B., Keller, W., Tybout, J., 2008. Openness and industrial responses in a Wal-Mart world: A case study of Mexican soaps, detergents and surfactant producers. World Economy 31, 1558-1580.

[21] Konzelmann, S., Wilkinson, F., Craypo, C., Aridi, R., 2007. The Export of National Varieties of Capitalism: The Cases of Wal-Mart and IKEA, in: Aridi, R., Craypo, C., Wilkinson, F. (Eds.), Varieties of Capitalism and New Institutional Deals. Edward Elgar, Cheltenham.

[22] Marx, L., Shaffer, G., 2007. Upfront payments and exclusion in downstream markets. Rand Journal of Economics 38, 823-843.

[23] Oligopoly Watch, 2003. Slotting fees and oligopolies, May 8, oligopolywatch.com/2003/05/08.html

[24] Raff, H., Schmitt, N., 2005. Endogenous vertical restraints in international trade. European Economic Review 49, 1877-1889.

[25] Raff, H., Schmitt, N., 2006. Exclusive dealing and common agency in International Markets. Journal of International Economics 68, 485-503.

[26] Raff, H., Schmitt, N., 2009. Buyer power in international markets. CESifo Working Paper 2755. 
[27] Rauch, J., 2001. Business and social networks in international trade. Journal of Economic Literature 39, 1177-1203.

[28] Rey, P., Thal, J., Vergé, T., 2005. Slotting allowances and conditional payments, mimeo.

[29] Richardson, M., 2004. Trade policy and access to retail distribution. Review of International Economics 12, 676-688.

[30] Shaffer, G., 1991. Slotting allowances and resale price maintenance: A comparison of facilitating practices. Rand Journal of Economics 22, 120 136.

[31] Sloan, C., 2006. 'Exclusive' is often lost in translation. Furniture Today 47, March 13.

[32] Smith, H., 2004. Who calls the shots in the global economy? www.pbs.org/wgbh/frontline/shows/walmart/secrets

[33] Spencer, B., Jones, R., 1991. Vertical foreclosure and international trade policy. Review of Economic Studies 56, 153-170.

[34] Villas-Boas, S.B., 2007. Vertical relationship between manufacturers and retailers: Inference with Limited Data. Review of Economic Studies 74, $625-652$.

[35] von Ungern-Sternberg, T., 1996. Countervailing power revisited. International Journal of Industrial Organization 14, 507-520. 


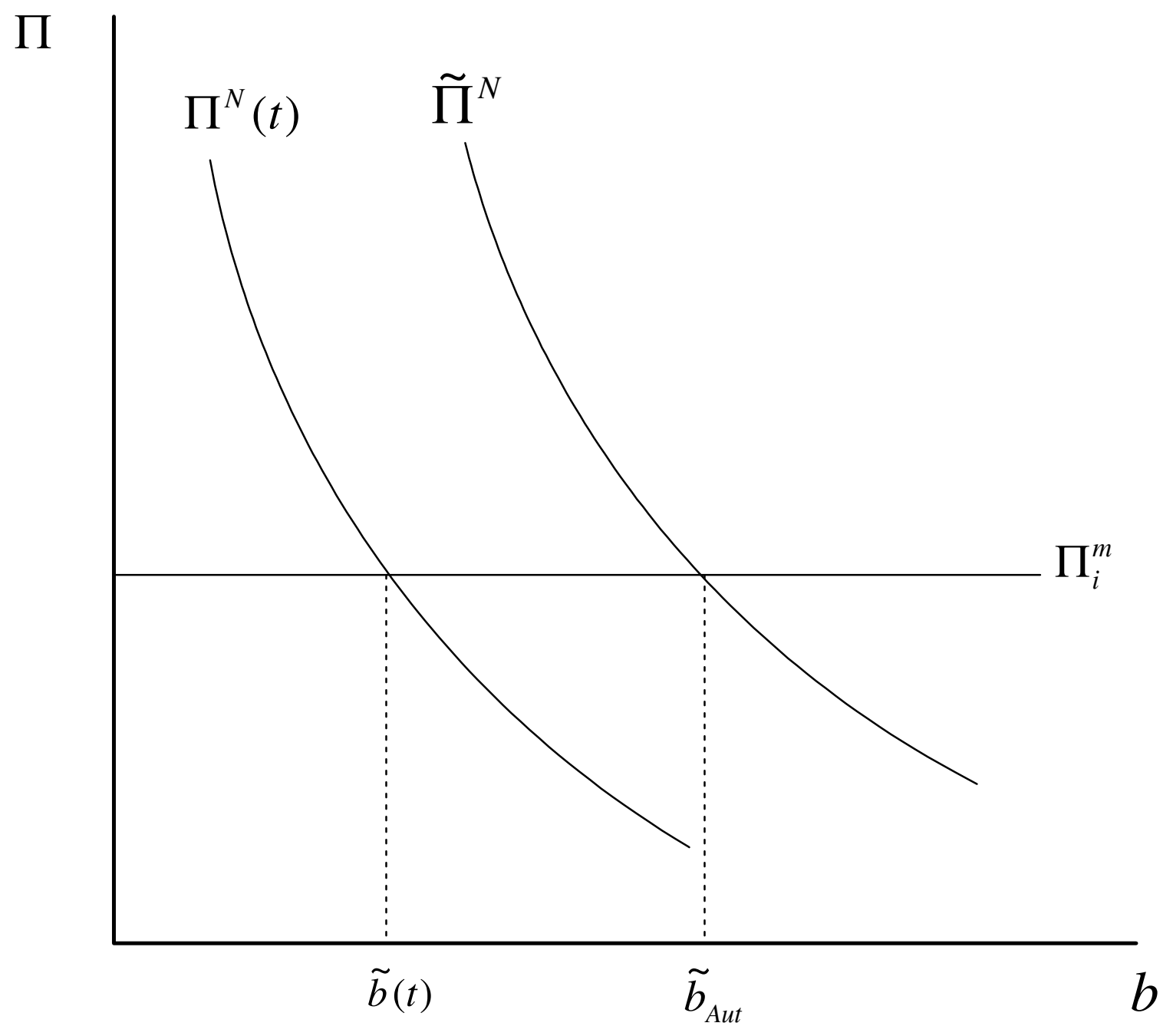

Figure 1 